\title{
A New Species of Paracoccus Ezzat and McConnell (Hemiptera: Pseudococcidae) from Southern Brazil
}

\author{
VC PACHECO dA Silva ${ }^{1,2}$, MB Kaydan ${ }^{3}$, J-F Germain ${ }^{4}$, M Botton $^{2}$ \\ ${ }^{1}$ Plant Protection Graduate Program, Plant Protection Dept, UFPel, Pelotas, RS, Brasil \\ ${ }^{2}$ Embrapa Grape and Wine, Bento Gonçalves, RS, Brasil \\ ${ }^{3}$ Imamoglu Vocational School, Çukurova Univ, Adana, Turkey \\ ${ }^{4}$ Anses, Laboratoire de la Santé des Végétaux, Unité d’entomologie et plantes invasives, Montferrier-sur-Lez, France
}

\section{Keywords}

Coccomorpha, mealybugs,

Neotropical region, scale insects, taxonomy

\section{Correspondence}

VC Pacheco da Silva, Embrapa Grape and Wine, Rua Livramento, 515, Cx postal 130, Bento Gonçalves, RS 95700-000, Brasil; vitorcezar@gmail.com

Edited by Takumasa Kondo - CORPOICA

Received 20 January 2016 and accepted 4 June 2016

(C) Sociedade Entomológica do Brasil 2016

\begin{abstract}
The worldwide mealybug genus Paracoccus Ezzat \& McConnell (Hemiptera: Coccomorpha: Pseudococcidae) has eight described Neotropical species, including two species known from Brazil. In this article, we describe a third species from Brazil: Paracoccus galzerae Pacheco da Silva \& Kaydan sp. n., based on the morphology of adult females collected on the roots of Conyza bonariensis (Asteraceae) in vineyards in Bento Gonçalves City, Rio Grande do Sul. A revised identification key including the new species is provided for the Neotropical region.
\end{abstract}

\section{Introduction}

Scale insects (Hemiptera: Sternorrhyncha: Coccomorpha) are small sap-sucking insects that occur associated with many plant families worldwide. In the Neotropical region, 1310 species have been recorded, with the families Coccidae, Diaspididae, and Pseudococcidae having the largest number of species and causing the most economic damage (García et al 2016).

The family Pseudococcidae, commonly called mealybugs, contains the second-largest number of scale insect species in the world. This family comprises a total of 2020 species, in two subfamilies with 260 genera (García et al 2016). In the Neotropical region, 44 genera have been recorded, of which Pseudococcus Westwood, Dysmicoccus Ferris, and Phenacoccus Cockerell are the most speciose (García et al 2016). In Brazil, 77 mealybug species have been recorded, with Pseudococcus and Dysmicoccus having the most species (García et al 2016).

Mealybugs are characterized by the presence of waxy and powdery secretions on the body surface. In general, they have an oval, elongated to rounded body, often dorsoventrally compressed, pinkish to grayish in color, and covered by white powdery wax in life (Cox \& Pearce 1983). Mealybugs are pests of many crops in all regions of the world, mostly because they produce honeydew that promotes the development of sooty mold, and also transmit plant viruses (Franco et al 2009, Daane et al 2012).

Hardy et al (2008) and Kaydan et al (2015) found that the family Pseudococcidae can be divided into two subfamilies, Phenacoccinae and Pseudococcinae. Adult females of Pseudococcinae are characterized by (i) tarsal digitules apically knobbed, (ii) claws either without denticle or, if present, with denticle poorly developed, (iii) quinquelocular pores usually absent, (iv) antennae generally with eight or fewer segments, and ( $\mathrm{v}$ ) anal ring with setose-like spinules (Hardy et al 2008, Kaydan et al 2015). In this subfamily, there are 13 genera with oral rim tubular ducts (or mushroom-type tubular ducts): Atrococcus Goux (with 26 species), Brasiliputo Williams \& Granara de Willink (1 species), Chorizococcus McKenzie (57 species), Colombiacoccus Williams \& Granara de Willink (1 species), Distichlicoccus Ferris (12 species), part 
of Humococcus Ferris (17 species), part of Leptococcus Reyne (10 species), Maconellicoccus Ezzat (8 species), Moystonia Williams (2 species), Paracoccus Ezzat \& McConnell (89 species), Pseudococcus Westwood (154 species), Spilococcus Ferris (47 species), and Vryburgia De Lotto (10 species). The exceptions are two genera that include species with and without oral rim tubular ducts: four species of Mirococcopsis Borchsenius and two species of Iberococcus Gómez-Menor Ortega have oral rim tubular ducts.

The genus Paracoccus differs from other genera sharing oral rim tubular ducts in having an anal lobe bar. The genus is well distributed worldwide, with 23 species in the Afrotropical region, 37 in the Australasian region, 12 in the Oriental region, 3 in the Palearctic region, 18 in the Nearctic region, and 8 in the Neotropical region excluding Mexico, but only 2 species, Paracoccus ascius Williams \& Granara de Willink and Paracoccus decorus Williams \& Granara de Willink, in Brazil (Williams \& Granara de Willink 1992, García et al 2016). At present, three groups of Paracoccus are recognized worldwide, the Neotropical, Afrotropical, and Australasian groups (Hardy et al 2008). In their worldwide phylogenetic tree, Hardy et al (2008) placed these three different groups in three different and unrelated clades (with Paracoccus nothofagicola Cox endemic in Australasia, Paracoccus marginatus Williams \& Granara de Willink and Paracoccus juniperi (Ehrhorn) from the Americas, and the type species Pseudococcus burnerae (Brain) from the Afrotropical region). Thus, it likely that Paracoccus is not monophyletic, as reported by Hardy et al (2008), and further studies are needed to clarify the status of these three zoogeographical groups.

In this study, a new Paracoccus species collected on roots of Conyza bonariensis L. (Asteraceae) in vineyards in southern Brazil is described and illustrated, based on adult female morphology. We also present an updated identification key to the species of Paracoccus found in the Neotropical region.

\section{Material and Methods}

\section{Sample collection}

Mealybugs were collected on roots of the weed Conyza bonariensis (Asteraceae), in a vineyard in Bento Gonçalves City, Serra Gaúcha Region, Rio Grande do Sul, Brazil, in two periods during the years 2014 and 2015. Roots with mealybugs were taken to the laboratory for examination.

\section{Morphological identification}

Female adult mealybugs were slide-mounted at the Plant Protection Department of Çukurova University, Adana, Turkey, and Anses, Laboratoire de la Santé des
Végétaux, Montferrier-sur-Lez, France, using the methods proposed by Kosztarab \& Kozár (1988) with modifications (using sterile water after $\mathrm{KOH}$ to clean the specimens with a fine brush). The specimens were identified using the keys of Williams \& Granara de Willink (1992) and Williams (2004).

The slides are stored in the Çukurova University Coccoidea collection, Adana, Turkey (KPTC) and at Anses, Laboratoire de la Santé des Végétaux, Montferrier-sur-Lez, France (ANSES/LSV). The holotype and one paratype are deposited in the Coccoidea Collection of the Museum Ramiro Gomes Costa (MRGC), Porto Alegre, Brazil.

\section{Morphometric methods}

The mealybugs were measured, and the main taxonomic characters were quantified under a Leica DM2500 phasecontrast compound microscope. All available material was measured. The morphological terms used here are based on Williams (2004) and Williams \& Granara de Willink (1992). All measurements are maximum dimensions (e.g., body width was recorded at the widest part) and are expressed as a range. Tarsal length excludes the claw. Setal lengths include the setal base. Cerarii are numbered after Williams \& Granara de Willink (1992), with cerarius 1 being on the head, anterior to the antenna, and cerarius 17 being on segment VIII.

The illustration and description were prepared by MBK and VCPS. The drawing represents a generalized individual based on several specimens used for the description. Each illustration is divided longitudinally, with the left half representing the dorsum and the right half the venter. Structural details are shown as enlargements around the central drawing and are drawn to different scales. Although translucent pores on the hind legs are located mostly on the dorsal surface, they are illustrated ventrally on the main drawing for convenience.

\section{Results}

\section{Genus Paracoccus Ezzat \& McConnell}

Paracoccus Ezzat and McConnell 1956: 37. Type species: Pseudococcus burnerae Brain, by original designation

Synonym: Gossypina Salazar 1972: 293. Type species: Gossypina glauca Salazar, by monotypy and original designation

Diagnosis (adapted from Williams \& Granara de Willink 1992, Williams 2004): Adult female. Body normally broadly oval, 1.2-4.7 mm long, 1.1-2.3 mm wide. Antennae normally 8-segmented. Labium 3-segmented, always longer than 
wide. Circulus present or absent, when present divided by an intersegmental line. Legs well developed, claw without a denticle; translucent pores usually present on hind coxa and tibia. Anterior and posterior ostioles present, anterior ostioles sometimes more weakly developed than posterior pair. Anal lobes usually well developed, each with ventral anal lobe bar. Anal ring typically with 6 anal ring setae.

Dorsum. Cerarii numbering up to 18 pairs (4-18), rarely absent entirely (Paracoccus reductus (Ferris)); each cerarius with usually 2 conical setae, except on head or thorax with occasionally 3 or 4 setae; auxiliary setae present on anal lobe cerarii only. Anterior and posterior ostioles present. Dorsal setae short and stiff, flagellate or short flagellate, sometimes slightly curved. Trilocular pores evenly distributed on dorsum, often in a cluster associated with each cerarius. Minute discoidal pores scattered, rarely not observed, of 2 sizes or present mainly on cerarii. Oral rim tubular ducts often present on margins of body, but also present medially and submedially, rarely entirely absent on dorsum. Oral collar tubular ducts rarely present; if present, located on margin of abdominal segments. Multilocular disc pores rarely present ( $P$. ascius).

Venter. Body setae flagellate. Trilocular pores evenly distributed. Minute discoidal pores sparse, rarely not observed. Oral rim tubular ducts frequently present. Oral collar tubular ducts of one or more sizes, varying in length and width. Multilocular disc pores present on abdominal segments, seldom on thorax, and rarely on head.

\section{Key to adult females of Paracoccus found in the Neotropical region excluding those known only from Mexico}

(Adapted from the key prepared by Williams \& Granara de Willink (1992))

1. Abdominal cerarii numbering 7 pairs or fewer $\ldots \ldots \ldots 2$

- Abdominal cerarii numbering 8 pairs . . . . . . 6

2. Multilocular disc pores present on venter of thorax ....3

- Multilocular disc pores absent from venter of thorax . . .5

3. Oral rim tubular ducts on dorsum few, present on abdomen only ... Paracoccus turriabensis Williams \& Granara de Willink - Oral rim tubular ducts on dorsum more numerous, present in rows across thorax and abdomen $\ldots \ldots \ldots \ldots \ldots . \ldots 4$ 4. Oral collar tubular ducts of only one size; clusters of oral collar tubular ducts next to anal lobe cerarii absent . . . . . . .............. P. decorus Williams \& Granara de Willink - Oral collar tubular ducts on ventral abdominal segments of two sizes; clusters of oral collar tubular ducts next to anal lobe cerarii present . . . . . . . . Paracoccus galzerae sp. $n$. 5. Oral collar tubular ducts present on ventral margins of thorax ........ Paracoccus lycopersici Ezzat \& McConnell
- Oral collar tubular ducts absent from ventral margins of thorax ........... Paracoccus solani Ezzat \& McConnell 6. Multilocular disc pores present on ventral lateral margins of thorax. . . . . . . . . . P. ascius Williams \& Granara de Willink - Multilocular disc pores absent from ventral lateral margins of thorax $\ldots \ldots \ldots \ldots \ldots \ldots \ldots \ldots \ldots \ldots \ldots \ldots \ldots$ 7. Oral rim tubular ducts absent from dorsum of anal lobe segment $\ldots \ldots \ldots \ldots \ldots \ldots \ldots \ldots \ldots \ldots \ldots \ldots \ldots \ldots \ldots \ldots$

- Oral rim tubular ducts present on dorsum of anal lobe segment .................... ... Paracoccus myrtacearum Williams \& Granara de Willink 8. Dorsal oral rim tubular ducts present on margins only ... ............ P. marginatus Williams \& Granara de Willink - Dorsal oral rim tubular ducts present in rows across the segments ........................ ... . . . . Paracoccus herreni Williams \& Granara de Willink

\section{Discussion}

Paracoccus galzerae Pacheco da Silva \& Kaydan sp. n. (Figs 1 and 2)

Material studied: Holotype adult female: Brazil, Bento Gonçalves, Rio Grande do Sul; S: 29¹1'8.96", W: $051^{\circ} 35^{\prime}$ 25.0"; on Conyza bonariensis L. (Asteraceae), 14.iv.2014 and 24.ii.2015, coll: V.C. Pacheco da Silva and Elisangela Caroline W. Galzer, MRGC: 2269. Paratypes: seven adult females, same data as holotype, ANSES/LSV 2 slides, MBK 1 slide, MRGC 1 slide (2270) and 3 slides in the collection of the first author.

\section{Adult female}

Appearance in life. Body oval, length up to $2.3 \mathrm{~mm}$ at maturity, yellowish, covered in thin layer of white wax (Fig 1). No filaments observed on margin of body

Description. Adult female. Body oval, 1.60-2.35 mm long, 0.90-1.32 mm wide. Eye marginal, 25-35 $\mu \mathrm{m}$ wide. Antenna 8-segmented, 260-370 $\mu \mathrm{m}$ long, with 4 fleshy setae, each 20.0-27.5 $\mu \mathrm{m}$ long; apical segment 75-95 $\mu \mathrm{m}$ long, 22.5-27.5 $\mu \mathrm{m}$ wide, with apical setae 23.5-30 $\mu \mathrm{m}$ long. Tentorium 113-130 $\mu \mathrm{m}$ long, 100-125 $\mu \mathrm{m}$ wide. Labium 3segmented, 80-95 $\mu \mathrm{m}$ long, 65-78 $\mu \mathrm{m}$ wide. Anterior spiracles $42.5-57.5 \mu \mathrm{m}$ long, $17.5-25 \mu \mathrm{m}$ wide across atrium; posterior spiracles 42.5-55.0 $\mu \mathrm{m}$ long, 22.5-30.0 $\mu \mathrm{m}$ wide across atrium. Circulus absent. Legs well developed; length data for posterior legs: coxa 112.5-167.5 $\mu \mathrm{m}$, trochanter+ femur 190-235 $\mu \mathrm{m}$, tibia + tarsus 205-240 $\mu \mathrm{m}$, claw 25.0$27.5 \mu \mathrm{m}$. Ratio of lengths of tibia + tarsus to trochanter $+\mathrm{fe}-$ mur 1.01-1.13:1; ratio of lengths of tibia to tarsus 1.69-2.20:1; 


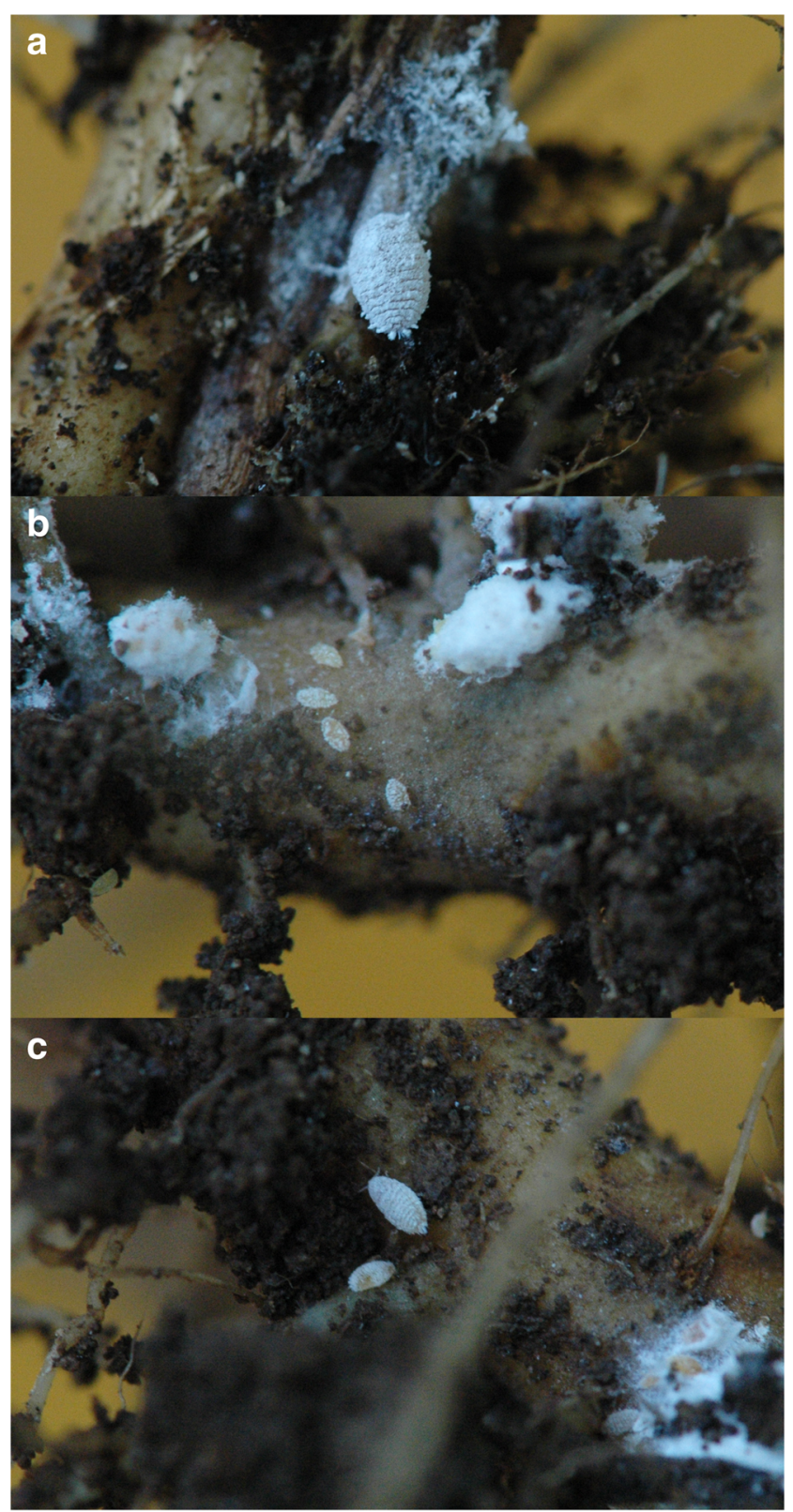

Fig. 1 Paracoccus galzerae Pacheco da Silva \& Kaydan sp. n. in life. A adult female; B first-instar nymphs; C second-instar nymphs.

ratio of length of hind trochanter + femur to greatest width of femur 3.62-4.47:1. Tarsal digitules capitate, each 32.5$47.5 \mu \mathrm{m}$ long. Claw digitules capitate, each 22.5-27.5 $\mu \mathrm{m}$. Translucent pores present on venter and dorsum of hind coxa and tibia, numbering 106-203 on coxa and 6-17 on tibia. Both pairs of ostioles present; anterior ostioles each with a total for both lips of 14-25 trilocular pores and 2-3 setae; posterior ostioles each with a total for both lips of 1246 trilocular pores and $3-5$ setae. Anal ring $45-60 \mu \mathrm{m}$ wide, with 6 setae, each seta $85-143 \mu \mathrm{m}$ long

Dorsum. Derm membranous, with 6-7 pairs of cerarii around body margin, each cerarius with 2 cerarian setae,
12.5-22.5 $\mu \mathrm{m}$ long; cerarius on abdominal segment II weakly developed with cerarian setae more slender than those of more posterior segments. Anal lobe cerarius with 15-20 trilocular pores associated with cerarian setae and $3-5$ spine-like auxiliary setae. Dorsal body setae short flagellate, 5-20 $\mu \mathrm{m}$ long, scattered on head and thorax, in single rows on abdominal segments. Trilocular pores $2.5-5.0 \mu \mathrm{m}$ in diameter, scattered over entire body. Minute discoidal pores 2.0-2.5 $\mu \mathrm{m}$ in diameter, also scattered over entire body. Oral rim tubular ducts totaling 111-141 on dorsum, each duct 8.8$12.5 \mu \mathrm{m}$ long, $2.5-3.8 \mu \mathrm{m}$ wide at mid-width, rim of duct opening 2.5-5.0 $\mu \mathrm{m}$ wide and distal width 5-8.8 $\mu \mathrm{m}, 31-$ 43 on head and thorax, and all abdominal segments (except last abdominal segment) as follows: I 11-13, II 11-14, III 10-15, IV 12-16, V 10-17, VI 6-9, VII 10-17. Multilocular disc pores on abdominal segments as follows: $\mathrm{V}$ o-6; $\mathrm{VI}$ o-8; VII 2-4, 4-5 $\mu \mathrm{m}$ in diameter

Venter. Setae flagellate, 7-100 $\mu \mathrm{m}$ long, longest setae medially on head. Apical setae of anal lobe 125-160 $\mu \mathrm{m}$ long. Trilocular pores and minute discoidal pores scattered over entire venter. Trilocular pores $2.5-3.8 \mu \mathrm{m}$. Oral collar tubular ducts concentrated on body margin and in single rows across all abdominal segments, of 2 sizes: larger ducts, $6.3-10.0 \mu \mathrm{m}$ long and 2.5-3.8 $\mu \mathrm{m}$ wide in submarginal areas and across abdominal segments; and smaller ducts $5.0 \mu \mathrm{m}$ long and $2.5 \mu \mathrm{m}$ wide, across abdominal segments as follows: I-III 715 ducts, IV 22-38, V 66-109, VI 83-120, VII 60-87, VIII+IX 13-30. Oral rim tubular ducts totaling $65-73$ on venter, absent on head, 22-37 ducts on thorax, and on abdominal segments as follows: I-III 20-28, II 7-11, III 4-8, IV 4-7, V $4-7, \mathrm{VI} \mathrm{5-7,} \mathrm{VII} \mathrm{4-12.} \mathrm{Multilocular} \mathrm{disc} \mathrm{pores} \mathrm{in} \mathrm{rows} \mathrm{on} \mathrm{ab-}$ dominal segments as follows: II-III 18-36, IV 34-74, V 81-128, VI 85-109, VII 74-108, VIII + IX 50-76; and 3-12 on thorax and head; each pore $5.0-6.3 \mu \mathrm{m}$ in diameter

Comments. Paracoccus galzerae is similar to $P$. decorus in (i) lacking a circulus and (ii) having multilocular disc pores present on the venter of the thorax. P. galzerae can be distinguished from $P$. decorus in having (i) two sizes of oral collar tubular ducts on the ventral abdominal segments (one size in $P$. decorus), (ii) clusters of oral collar tubular ducts next to the anal lobe cerarii (absent in $P$. decorus), and (iii) oral rim tubular ducts on the dorsal head (absent in $P$. decorus). $P$. galzerae is closest to $P$. solani in (i) having two sizes of oral collar tubular ducts on the ventral abdominal segments, (ii) lacking oral collar tubular ducts on the ventral margins of the thorax, and (iii) having oral rim tubular ducts in rows across most abdominal segments of dorsum. However, $P$. galzerae can be readily distinguished from $P$. solani in having (i) multilocular disc pores on the dorsum (absent in P. solani), (ii) multilocular disc pores on the venter of the thorax and on 
Fig. 2 Paracoccus galzerae Pacheco da Silva \& Kaydan sp. n., adult female.

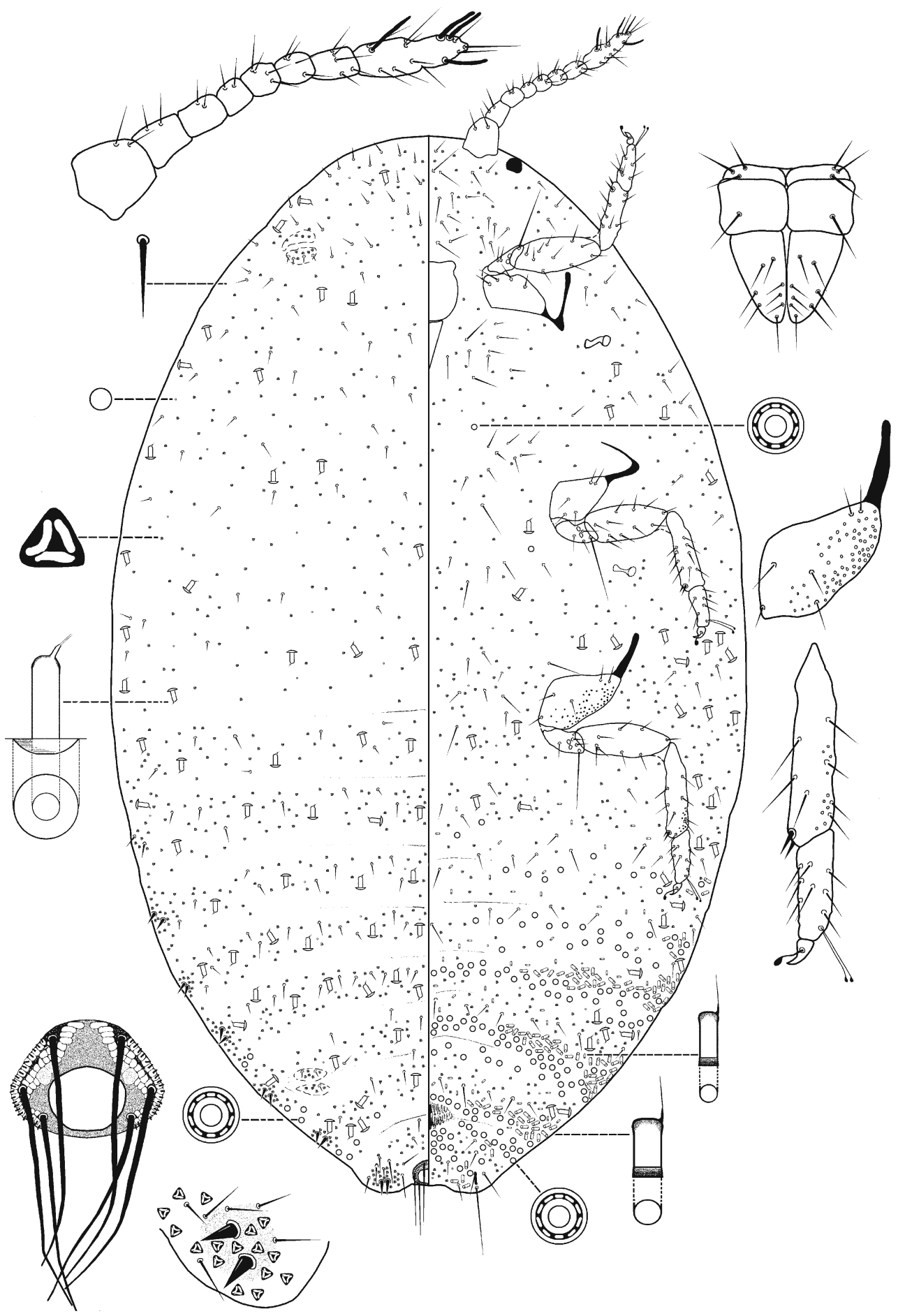

the margin of the abdomen (no multilocular disc pores on the thorax in $P$. solani, multilocular disc pores never reaching margin in $P$. solani), and (iii) number of multilocular disc pores on abdominal segments larger in $P$. galzerae than in P. solani (in P. solani as follows: I-III O, IV 15, V 24, VI 37, VII 45, VIII-IX 23 according to the original description by Ezzat \& McConnell 1956). The most important character to distinguish these two species is the presence or absence of multilocular disc pores on the margin of the abdominal segments and on the dorsum (multilocular disc pores present on margin and dorsum in $P$. galzerae, lacking in $P$. solani). Although environmental conditions such as the temperature (e.g., constant laboratory versus variable field conditions), time of year (e.g., summer versus winter) when the 
mealybugs develop, and/or the feeding site on the plant (roots versus stems or crowns) can affect the number of oral collar tubular ducts, multilocular disc pores, and other pores on the body surface (Charles et al 2000, Cox 1983; Marotta \& Tranfaglia 1995), the positions of the features are important to delineate the taxa. Although the number of multilocular disc pores can change with environmental conditions, the position of the pores is consistent in each species.

Distribution. Brazil, Rio Grande do Sul State, Bento Gonçalves City

\section{Host plant. Conyza bonariensis L. (Asteraceae)}

Etymology. This species is named after one of the collectors, Elisângela Caroline Weber Galzer (Embrapa Grape and Wine, Bento Gonçalves, RS, Brazil).

Acknowledgments We are grateful to Danielle Matile-Ferrero from the Muséum national d'Histoire naturelle, Paris, France, for examining the slides and for her remarks about this species; to Thibaut Malausa from the Université Nice Sophia Antipolis for his generous support; to Takumasa Kondo and the anonymous reviewers for their helpful suggestions that improved the manuscript considerably; and to CNPq for the scholarship awarded to VCPS.

\section{References}

Charles JG, Froud KJ, Henderson RC (2000) Morphological variation and mating compatibility within the mealybugs Pseudococcus calceolariae and $P$. similans (Hemiptera: Pseudococcidae), and a new synonymy. Syst Entomol 25:285-294
Cox JM (1983) An experimental study of morphological variation in mealybugs (Homoptera: Coccoidea: Pseudococcidae). Syst Entomol 8:361-382

Cox JM, Pearce MJ (1983) Wax produced by dermal pores in three species of mealybug (Homoptera: Pseudococcidae). Int J Insect Morphol Embryol 12:235-248

Daane KM, Almeida RPP, Bell VA, Walker JTS, Botton M, Fallahzadeh M, Mani M, Miano JL, Sforza R, Walton VM, Zaviezo T (2012) Biology and management of mealybugs in vineyards. In: Bostanian NJ, Vincent C, Isaacs R (eds) Arthropod management in vineyards. Springer Netherlands Press, Dordrecht, pp 271-307, 484p

Ezzat YM, McConnell HS (1956) A classification of the mealybug tribe Planococcini (Pseudococcidae: Homoptera). Bull Md Agric Exp Stat A-84:3-108

Franco JC, Zada A, Mendel Z (2009) Novel approaches for the management of mealybug pests. In: Ishaaya I, Horowitz AR (eds) Biorational control of arthropod pests. Springer Science + Business Media, New York, pp 233-278, 393p

García M, Denno B, Miller DR, Miller GL, Ben-Dov Y, Hardy NB (2016) ScaleNet: a literature-based model of scale insect biology and systematics. (www.scalenet.info). Last access date: 18 April 2016

Hardy NB, Gullan PJ, Hodgson CJ (2008) A subfamily-level classification of mealybugs (Hemiptera: Pseudococcidae) based on integrated molecular and morphological data. Syst Entomol 33:51-71

Kaydan MB, Kozár F, Hodgson C (2015) A review of the phylogeny of Palaearctic mealybugs (Hemiptera: Coccomorpha: Pseudococcidae). Arthropod Syst Phylo 73:175-195

Kosztarab M, Kozár F (1988) Scale insects of Central Europe. DrW. Junk Publishers, Dordrecht, $456 \mathrm{p}$

Marotta S, Tranfaglia A (1995) Variability of morphological characters and its use in the systematics of mealybugs (Homoptera: Pseudococcidae). Isr J Entomol 29:67-73

Salazar TJ (1972) Contribución al conocimiento de los Pseudococcidae del Perú. Rev Peru Entomol 15:277-303

Williams DJ (2004) Mealybugs of Southern Asia. The Natural History Museum Press, Kuala Lumpur, 896p

Williams DJ, Granara de Willink MC (1992) Mealybugs of Central and South America. CAB International, Wallingford, 635p 